\title{
INFLUENCE OF MYCORRHIZAL FUNGI ON THE GROWTH AND DEVELOPMENT OF SANDY EVERLASTING Helichrysum arenarium (L.) Moench
}

\author{
Anna Katarzyna Sawilska, Ewa Jendrzejczak* \\ Monika Welc, Barbara Kieliszewska-Rokicka** \\ *University of Technology and Life Sciences, Faculty of Agriculture, Department of Botany and Ecology \\ Prof. S. Kaliskiego 7, building 3.1, 85-789 Bydgoszcz, Poland \\ e-mail: sawilska@utp.edu.pl \\ **Kazimierz Wielki University, Institute of Environmental Biology, Department of Mycology and Mycorrhiza \\ Al. Ossolińskich 12, 85-093 Bydgoszcz, Poland
}

Received: 5.01.2009

\section{Abstract}

The significance of root colonization by mycorrhizal fungi for the growth and development of Helichrysum arenarium was investigated in two independent experiments. In the first experiment the association of root colonization level with the pluviothermal conditions within the growing season and the age of a natural plant population was analyzed. In the second one, under controlled conditions, the influence of artificial inoculation with the arbuscular fungus Glomus intraradices on the features of plants raised from achenes was studied. It was shown that hydrothermal conditions during blooming period had a greater influence on reproduction processes of sandy everlasting than both the population age (the secondary succession progress) and the level of root colonization by mycorrhizal fungi. High amount of precipitation at plant generative development phase positively influences the potential and actual fertility of ramets. The presence of arbuscular fungus in the soil favors the growth and development of sandy everlasting specimens at their early growing stages: they have a better-developed root system and a greater photosynthetic area.

Key words: Helichrysum arenarium (L.) Moench, generative potential, potential and actual fertility, arbuscular mycorrhiza, inoculation of growing medium

\section{INTRODUCTION}

Helichrysum arenarium (L.) Moench is a perennial belonging to the Asteraceae family. The species is under partial protection in Poland. Its inflorescences collected at the beginning of the blooming period (Inflorescentia Helichrysi $=$ Flos Stoechados citrini $)$ constitute a raw material for a number of medicinal preparations (FP 2002) used for treatment of digestive system diseases (O ż a r o w s k i , 1983; G a w r o n $\mathrm{G} \mathrm{z} \mathrm{e} 11$ a et al. 2003). Sandy everlasting is also a decorative and erosion-preventing plant.

Because of many desirable features of the plant, in the 1970s there were some attempts at growing it in the fields (Fij a łkow s ki and Seroczyń s ka, 1974; P a chol ak and Z a łęcki, 1979), but they eventually failed (B u c h w a ld, 1992). The probable reason for these failures was underestimation of sandy everlasting symbiosis with mycorrhizal fungi (W e lc et al. 2007).

According to the contemporary knowledge, mycorrhizal fungi are present in most inland plant communities. Arbuscular mycorrhiza (AM, endomycorrhiza) is regarded as the oldest mycorrhiza type and it is the most abundant in nature ( $\mathrm{S} \mathrm{m} \mathrm{i} \mathrm{th} \mathrm{and} \mathrm{R} \mathrm{e} \mathrm{a} \mathrm{d,} \mathrm{1997;}$ B ł a s z k o w s ki, 2004). The ability of many plant species to colonize sandy soils that are infertile, acidic and drain out rapidly, depends on their symbiosis with arbuscular fungi. The presence of these fungi in the root system makes it easier for the plant to draw nutrients from the soil, especially those which are poorly mobile or in short supply, like phosphorus, nitrogen, zinc and copper (G e m m a and K o s k e, 1997; K o s ke and Ge m m a, 1997; Th o m p s o n, 1987; B a re a et al. 1991). Plant roots colonized by arbuscular fungi are naturally protected against some pathogens (G r a h a m, 2001). They also have an increased ability to extract water from the soil, which reduces their vulnerability to water shortage periods ( $\mathrm{S}$ a n c he zDiaz and Honrubia, 1994). Extramatrical hyphae that penetrate the soil constitute the main absorption surface as well as a water and nutrient distribution 
system. Arbuscular fungi take for their own metabolism up to $20 \%$ of carbon assimilated by the host plant (J a k obsen and Rosendah 1, 1990).

Sandy everlasting belongs to a group of plants that exhibit an ability to invade areas disturbed by either human activity or natural disasters. The plants can be found on dunes and in abandoned fields, on soils that are deficient in mineral nutrients and easily drained (Rutkow ski, 2004). Although such harsh conditions do not promote either growth or development of the plants, the succession process becomes more vigorous with colonization of these areas by mycorrhizal fungi (Gucwa - Prze pióra and Turnau, 2001).

The aim of the investigation was to evaluate the influence of mycorrhiza on the growth and development dynamics of $H$. arenarium. The influence of root colonization by arbuscular fungi on the mass of underground and aboveground plant parts, the number of generative shoots, the plant density as well as the potential and actual fertility of the plants from natural stands were analyzed in detail. The effect of the soil inoculation with mycorrhizal fungi on selected morphological features of plants raised from achenes was also investigated.

This work was supported by grant from Ministry of Science and Higher Education No. 2P06R 073 30.

\section{MATERIALS AND METHODS}

Two experiments on sandy everlasting plants originating from natural stands were conducted.

In the first experiment in the years 2005-2007 phenological observations were conducted and measurements were taken in two selected natural stands with sandy everlasting populations. Both grow in abandoned fields on clayey sand or loose sandy soils (T r z c i ń s k i, 1989). The population I, located in the outskirts of Bydgoszcz (Fordon district), is a part of an Diantho-Armerietum elongatae K raus c h 1959 association at an advanced stage of secondary succession. The population II, located in the village of Łosiny in the Bory Tucholskie forest complex, is a part of Spergulo vernalis-Corynephoretum (R.Tx. 1928) Libb. 1933 association that exhibits some features of an earlier succession stage ( $\mathrm{M}$ a t u s z k i e w i c z, 2005).

In permanent sample plots randomly selected at both locations the density of shoots was determined each year. During the blooming period in the vicinity of these sample plots 30 plants (ramets) were collected. The plants were analyzed using methods proposed by F a li ń s k a (2002). The number of generative and vegetative shoots per each ramet was counted and their fresh and air-dry mass was measured. The number of inflorescences and the number of flowers in inflorescences (potential fertility) were estimated. Actual fertility measured as the number of achenes per inflorescence and per ramet was also determined.

Weather conditions at the generative stage of sandy everlasting development were analyzed based on data gathered at meteorological stations in Bydgoszcz and Chojnice. Seljainov's $k$ index (B a c et al. 1998) was applied for the evaluation of hydrothermal conditions:

$$
\begin{gathered}
k=\frac{\sum P}{0,1 \sum t}=\frac{\text { season's total precipitation }}{0,1 \text { (seasons's sum of temperature) }} \\
\text { where } k<1 \text { indicates a drought period. }
\end{gathered}
$$

In the second experiment conducted in the year 2007 the influence of various soil treatment on the growth of plants obtained from achenes (fruits) collected from a natural stand in the previous year was investigated. The plants were grown in pots filled with soil taken from beneath wild specimens of sandy everlasting. The experiment was designed as a $2 \times 2$ arrangement of treatments.

The following treatments (regarded as factors) were applied in the experiment:

A. soil sterilization (soil samples were autoclaved in $105^{\circ} \mathrm{C}$ during 30 minutes; the procedure was repeated after two days): yes/no;

B. inoculation of the soil with the arbuscular fungus Glomus intraradices BEG 87: yes/no.

The inoculum of the arbuscular fungus $G$. intraradices BEG 87 originated from the pot culture of corn (Zea mays L.) deposited at the European Bank for Glomeromycota. Each medium inoculated was treated with $10 \mathrm{~g}$ of inoculum per $1 \mathrm{~kg}$ of the soil.

Soil types involved in the experiments described in this work were named after their granulation. A natural sand served as a non-treatment control.

After five months of growing, the plants were subject to biometric measurements. The fresh and airdry mass of plants, the length of their root system as well as their photosynthetic area were determined.

Samples consisting of soil blocks with whole plants rooted in them obtained from both experiments were analyzed to asses the level of root colonization by mycorrhizal fungi. Roots were removed from soil samples, rinsed with tap water and cut into $1 \mathrm{~cm}$ pieces. Five hundred milligrams of fine roots were prepared for assessment of arbuscular mycorrhiza (AM) by clearing with $10 \% \mathrm{KOH}$ and staining with trypan blue according to the method of Kormanik and McGraw (1982). AM colonization was assessed using the magnified intersection method according to M c Go ni g le et al. (1990). For each sample root segments (of the total length $80 \mathrm{~cm}$ ) were observed un- 
der 100x magnification using light microscope (Zeiss) equipped with an Eyepiece and built-in crosshair. Mycorrhizal structures (arbuscules, vesicles, hyphae, coils) and non-mycorrhizal endophytes were recorded. $\mathrm{AM}$ and non-AM colonization was calculated as the percentage of root length colonized (\% RLC).

Statistical analysis was performed using EXCEL and STATISTICA 8 PL software.

\section{RESULTS}

Weather conditions during sandy everlasting growing periods in the years 2005-2007 were similar at both locations of the field studies (Tab. 1). Typical differences in pluviothermal conditions were reported: the precipitation in Bydgoszcz is usually lower but the air temperature higher than in Bory Tucholskie (data for Chojnice). A vigorous generative development of Helichrysum arenarium occurs in June-July. These months in 2005 were rather dry, especially in Bydgoszcz. In 2006 very dry June and July were followed by a humid August. These months in 2007 were especially rainy, and the weather conditions in August were close to the many-year norm.

The level of AM root colonization in $H$. arenarium from natural stands varied and depended upon the time and site of sample collection (Tab. 2). It attained the highest value in 2005, when hyphae and vesicles prevailed. It was by $35.1 \%$ higher than that recorded in the next year. The colonization level by various forms of mycorrhizal fungi in 2007 was also higher by $15.2 \%$ on average than in 2006 . The roots of sandy everlasting were also sometimes colonized by non-mycorrhizal fungi, mainly Rhizoctonia sp. and Oomycetes sp. $(\mathrm{RLC}=2.2-5.3 \%)$.

The generative potential of $H$. arenarium populations studied, measured as the degree of development and percentage of generative shoots, turned out to be significantly associated with weather conditions, but independent of the AM colonization level (Tabs 1, 2, 3 ). The above-mentioned variables attained their highest values in 2006, when the most intense precipitation during the blooming period (in August) was recorded. However, in the two preceding months (June and July), at the vegetative development and inflorescence bud period, the weather was hot and dry. Under prolonging drought conditions in 2005 the plants produced more tiny ramets with many vegetative shoots, while intense precipitation in June and July 2007 promoted the development of underground plant parts (Tabs 1, 3).

The number of ramets decreased at both locations studied. This phenomenon was especially marked in the population II where the number of ramets in 2006 decreased 2.5-fold compared to the previous year. In 2007 the one-year decrease was even more pronounced (3-fold). The drop in the number of ramets was not accompanied by differences in the number of flowers and fruits produced by the plants. It is noteworthy that the number of flowers per inflorescence and the number of set fruits almost did not vary either with the year of study or the population. In 2006, under more suitable conditions for flowering, the number of flowers and achenes per ramet was 8-fold (population I) and 2.5-fold (population II) higher than in 2005. This emphasizes the significance of good water conditions for intensive flowering and fruiting of the plants. In 2007 a low number of sandy everlasting ramets influenced the actual fertility per area unit, nevertheless the flowering was more intensive than in dry 2005 (Tabs 3, 4).

In 2006 many morphological features of $H$. arenarium attained their highest values, but this was not associated with a more intensive AM colonization (Tabs 2, 3, 4) and might be caused by weather conditions which did not promote the development of AM fungi (at the beginning of 2006 low precipitation and temperature values were recorded).

Results of the laboratory experiment showed that soil sterilization affected the morphological features of plants raised from achenes sown into the soil (Tab. 5). Specimens growing on a sterilized sand from natural stands of sandy everlasting had a lower fresh mass of shoots and root system, lower ratios of dry mass of particular plant parts to the total mass, shorter roots, and a smaller photosynthetic area than plants growing on a non-sterilized soil. The amendment of the sterilized soil with inoculum of arbuscular fungus Glomus intraradices BEG 87 resulted in an increase in all morphological features analyzed. Significant differences were found in the fresh mass of whole plants, fresh mass of shoots and root system, root length and photosynthetic area. The ratios of dry mass of particular plant parts to the total mass attained their highest values for sandy everlasting specimens growing on a non-sterilized sand from natural stands augmented with the inoculum. However, significant differences in these features were found only for the roots (Tab. 5).

The level of AM colonization of plants grown from achenes varied with the soil type and treatment (Tab. 6). For the plants grown on the natural sandy soil it was 5\% RLC, while for specimens from the sterilized and then inoculated soil it was higher by $3.2 \%$ RLC. The AM colonization level was the highest $22.8 \%$ RLC) and the most variable for plants grown on the sandy soil from natural stands augmented with the mycorrhizal inoculum of Glomus intraradices (hyphae, vesicles and arbuscules). In seedling roots no non-mycorrhizal endophytic fungi were found. 
Table 1

Pluviothermal conditions at the sandy everlasting development phase in the years 2005-2007. Data from meteorological stations at Bydgoszcz and Chojnice.

\begin{tabular}{|c|c|c|c|c|c|c|c|}
\hline \multirow{3}{*}{ Year } & \multirow{3}{*}{ Month } & \multicolumn{6}{|c|}{ Location } \\
\hline & & \multicolumn{3}{|c|}{ Bydgoszcz (population I) } & \multicolumn{3}{|c|}{ Chojnice (population II) } \\
\hline & & $\begin{array}{c}\text { Total } \\
\text { precipitation } \\
{[\mathrm{mm}]}\end{array}$ & $\begin{array}{c}\text { Average } \\
\text { temperature } \\
{\left[{ }^{\circ} \mathrm{C}\right]}\end{array}$ & $k$ index & $\begin{array}{c}\text { Total } \\
\text { precipitation } \\
{[\mathrm{mm}]}\end{array}$ & $\begin{array}{c}\text { Average } \\
\text { temperature } \\
{\left[{ }^{\circ} \mathrm{C}\right]}\end{array}$ & $k$ index \\
\hline \multirow{4}{*}{2005} & June & 30.5 & 14.9 & 0.68 & 40.0 & 14.5 & 0.92 \\
\hline & July & 33.6 & 19.4 & 0.56 & 77.0 & 18.8 & 1.32 \\
\hline & August & 43.4 & 16.3 & 0.88 & 58.1 & 16.0 & 1.17 \\
\hline & $\begin{array}{l}\text { June - } \\
\text { August }\end{array}$ & 107.5 & 16.9 & 0.70 & 175.1 & 16.5 & 1.16 \\
\hline \multirow{4}{*}{2006} & June & 21.8 & 16.8 & 0.43 & 24.8 & 16.6 & 0.50 \\
\hline & July & 24.2 & 22.4 & 0.35 & 12.6 & 21.9 & 0.19 \\
\hline & August & 129.0 & 16.6 & 2.51 & 154.1 & 16.6 & 2.99 \\
\hline & $\begin{array}{l}\text { June - } \\
\text { August }\end{array}$ & 175.0 & 18.6 & 1.02 & 191.5 & 18.4 & 1.24 \\
\hline \multirow{4}{*}{2007} & June & 105.5 & 18.2 & 1.93 & 121.9 & 17.5 & 2.32 \\
\hline & July & 104.7 & 18.0 & 1.88 & 114.9 & 16.9 & 2.19 \\
\hline & August & 42.1 & 17.8 & 0.76 & 68.3 & 17.3 & 1.27 \\
\hline & $\begin{array}{l}\text { June - } \\
\text { August }\end{array}$ & 252.3 & 18.0 & 1.52 & 305.1 & 17.4 & 1.90 \\
\hline
\end{tabular}

Table 2

The level of sandy everlasting root colonization by AM structures for different locations and dates of sample collection [\%RLC]*).

\begin{tabular}{|c|c|c|c|c|c|}
\hline \multirow{3}{*}{ Year } & \multirow{3}{*}{ AM structures } & \multicolumn{4}{|c|}{ Location and date of sample collection } \\
\hline & & \multicolumn{2}{|c|}{$\begin{array}{c}\text { Bydgoszcz } \\
\text { (population I) }\end{array}$} & \multicolumn{2}{|c|}{$\begin{array}{c}\text { Łosiny } \\
\text { (population II) }\end{array}$} \\
\hline & & 15. June & 15. October & 15. June & 15. October \\
\hline \multirow{6}{*}{2005} & Hyphae & 41.2 & 28.4 & 33.4 & 28.6 \\
\hline & Vesicles & 24.9 & 2.7 & 15.9 & 4.0 \\
\hline & Arbuscules & 0.0 & 0.0 & 0.5 & 0.0 \\
\hline & Coils & 0.0 & 0.0 & 0.0 & 0.0 \\
\hline & Total & 66.1 & 31.1 & 49.7 & 32.6 \\
\hline & On average & \multicolumn{2}{|c|}{48.6} & \multicolumn{2}{|c|}{41.2} \\
\hline \multirow{6}{*}{2006} & Hyphae & 6.3 & 6.3 & 8.5 & 8.5 \\
\hline & Vesicles & 0.0 & 1.9 & 0.0 & 1.9 \\
\hline & Arbuscules & 1.9 & 0.0 & 1.9 & 0.0 \\
\hline & Coils & 0.7 & 0.7 & 0.3 & 0.3 \\
\hline & Total & 8.9 & 8.9 & 10.7 & 10.7 \\
\hline & On average & \multicolumn{2}{|c|}{8.9} & \multicolumn{2}{|c|}{10.7} \\
\hline \multirow{6}{*}{2007} & Hyphae & 7.8 & 27.4 & 10.5 & 17.2 \\
\hline & Vesicles & 1.5 & 5.4 & 4.1 & 2.0 \\
\hline & Arbuscules & 5.1 & 5.2 & 6.9 & 3.6 \\
\hline & Coils & 0.9 & 1.6 & 0.3 & 0.8 \\
\hline & Total & 14.8 & 39.6 & 21.8 & 23.6 \\
\hline & On average & \multicolumn{2}{|c|}{27.2} & \multicolumn{2}{|c|}{22.7} \\
\hline
\end{tabular}

*) Root Lenght Colonized = the percentage of root length colonized by mycorrhizal fungi 
Table 3

Generative potential of sandy everlasting at peak flowering (July - August) for both populations in the years 2005-2007.

\begin{tabular}{|c|c|c|c|c|c|c|c|}
\hline \multirow[b]{2}{*}{ 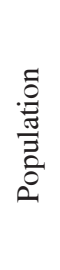 } & \multirow[b]{2}{*}{ Year } & \multicolumn{3}{|c|}{ Single clump (ramet) } & \multicolumn{3}{|c|}{ Per $1 \mathrm{~m}^{2}$} \\
\hline & & $\begin{array}{c}\text { Dry mass of } \\
\text { the clump } \\
{[\mathrm{g}]}\end{array}$ & $\begin{array}{l}\text { The ratio of } \\
\text { dry mass of } \\
\text { aboveground } \\
\text { parts to the total } \\
\text { dry mass [\%] }\end{array}$ & $\begin{array}{l}\text { The number } \\
\text { of generative } \\
\text { shoots }\end{array}$ & $\begin{array}{c}\text { The number } \\
\text { of clumps } \\
\text { (ramets) }\end{array}$ & $\begin{array}{l}\text { Total number } \\
\text { of clumps }\end{array}$ & $\begin{array}{c}\text { The number } \\
\text { of generative } \\
\text { shoots to the total } \\
\text { number of shoots } \\
{[\%]}\end{array}$ \\
\hline \multirow{3}{*}{ I } & 2005 & 1.14 & 57.0 & 1.9 & 29 & 117 & 47.7 \\
\hline & 2006 & 4.64 & 74.4 & 5.1 & 17 & 96 & 91.8 \\
\hline & 2007 & 2.07 & 51.1 & 3.0 & 14 & 46 & 90.1 \\
\hline \multirow{3}{*}{ II } & 2005 & 1.73 & 65.5 & 2.7 & 92 & 411 & 60.3 \\
\hline & 2006 & 2.50 & 70.1 & 4.4 & 36 & 169 & 93.4 \\
\hline & 2007 & 1.74 & 57.7 & 3.0 & 11 & 36 & 88.7 \\
\hline
\end{tabular}

Table 4

Potential and actual fertility per clump (ramet) and per area unit in the years 2005-2007.

\begin{tabular}{|c|c|c|c|c|c|c|c|c|}
\hline \multirow[b]{2}{*}{ 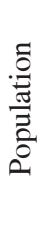 } & \multirow[b]{2}{*}{ Year } & \multirow[b]{2}{*}{$\begin{array}{l}\text { The number } \\
\text { of flower } \\
\text { heads per } \\
\text { clump }\end{array}$} & \multicolumn{2}{|c|}{ Potential fertility } & \multicolumn{2}{|c|}{ Actual fertility } & \multirow[b]{2}{*}{$\begin{array}{c}\text { Fertility } \\
\text { index } \\
{[\%]}\end{array}$} & \multirow[b]{2}{*}{$\begin{array}{l}\text { Actual fertility } \\
\text { per } 1 \mathrm{~m}^{2} \\
\text { [thousands of } \\
\text { achenes] }\end{array}$} \\
\hline & & & $\begin{array}{l}\text { The number } \\
\text { of flowers per } \\
\text { capitulum }\end{array}$ & $\begin{array}{l}\text { The number } \\
\text { of flowers } \\
\text { per clump } \\
\text { (ramet) }\end{array}$ & $\begin{array}{l}\text { The number } \\
\text { of achenes } \\
\text { per capitulum }\end{array}$ & $\begin{array}{l}\text { The number } \\
\text { of achenes } \\
\text { per clump } \\
\text { (ramet) }\end{array}$ & & \\
\hline \multirow{3}{*}{ I } & 2005 & 79.2 & 40.6 & 3216 & 34.3 & 2717 & 84.5 & 152.2 \\
\hline & 2006 & 591.6 & 43.7 & 25853 & 37.4 & 22126 & 85.6 & 1197.1 \\
\hline & 2007 & 237.4 & 46.1 & 12606 & 40.6 & 11100 & 88.1 & 466.2 \\
\hline \multirow{3}{*}{ II } & 2005 & 160.4 & 43.9 & 7042 & 38.1 & 6111 & 86.8 & 1515.5 \\
\hline & 2006 & 409.2 & 42.4 & 17350 & 36.9 & 15099 & 87.0 & 2400.7 \\
\hline & 2007 & 215.4 & 42.4 & 9133 & 37.7 & 8121 & 88.9 & 259.9 \\
\hline
\end{tabular}


Table 5

The influence of soil type used in laboratory experiments on biometric features of sandy everlasting specimens raised from achenes.

\begin{tabular}{|c|c|c|c|c|}
\hline \multirow{2}{*}{ Soil sterilization } & \multicolumn{2}{|c|}{ Soil inoculation } & \multirow{2}{*}{ On average } & \multirow{2}{*}{$\begin{array}{c}\mathrm{NIR}_{\mathrm{p}=0.05} \text { for } \\
\text { inoculation effects }\end{array}$} \\
\hline & No inoculation & Inoculation & & \\
\hline \multicolumn{5}{|c|}{ Fresh mass: } \\
\hline of the whole plant $[\mathrm{g}]$ & & & & \\
\hline No sterilization & 0.157 & 0.108 & 0.132 & Insignificant \\
\hline Sterilization & 0.102 & 0.181 & 0.141 & 0.040 \\
\hline On average & 0.129 & 0.144 & 0.136 & 0.030 \\
\hline \multicolumn{5}{|c|}{ of the aboveground parts [g] } \\
\hline No sterilization & 0.127 & 0.091 & 0.109 & Insignificant \\
\hline Sterilization & 0.079 & 0.135 & 0.107 & 0.031 \\
\hline On average & 0.103 & 0.113 & 0.108 & Insignificant \\
\hline \multicolumn{5}{|c|}{ of the underground parts $[\mathrm{g}]$} \\
\hline No sterilization & 0.030 & 0.017 & 0.023 & Insignificant \\
\hline Sterilization & 0.023 & 0.046 & 0.034 & 0.016 \\
\hline On average & 0.026 & 0.031 & 0.028 & Insignificant \\
\hline \multicolumn{5}{|c|}{ Percentage of dry mass: } \\
\hline No sterilization & 17.9 & 26.0 & 21.9 & Insignificant \\
\hline Sterilization & 12.9 & 14.8 & 13.8 & Insignificant \\
\hline On average & 15.4 & 20.4 & 17.9 & Insignificant \\
\hline \multicolumn{5}{|c|}{ of the aboveground parts [g] } \\
\hline No sterilization & 23.1 & 36.4 & 29.7 & 8.1 \\
\hline Sterilization & 21.2 & 21.7 & 21.4 & Insignificant \\
\hline On average & 22.1 & 29.0 & 25.5 & Insignificant \\
\hline \multicolumn{5}{|c|}{ Length of the root system [mm] } \\
\hline No sterilization & 76.3 & 61.1 & 68.7 & 6.6 \\
\hline Sterilization & 68.5 & 84.6 & 76.5 & 16.1 \\
\hline On average & 72.4 & 72.8 & 72.6 & Insignificant \\
\hline \multicolumn{5}{|c|}{ Leaf area of a single plant $\left[\mathrm{mm}^{2}\right]$} \\
\hline No sterilization & 63.2 & 63.4 & 63.3 & Insignificant \\
\hline Sterilization & 47.4 & 71.6 & 59.5 & 6.6 \\
\hline On average & 55.3 & 67.5 & 61.4 & 9.0 \\
\hline
\end{tabular}


Table 6

The level of sandy everlasting root colonization by AM fungus structures for different soil media [\%RLC].

\begin{tabular}{lcccc}
\hline & \multicolumn{3}{c}{ Medium } \\
\cline { 2 - 5 } Mycelium form & Natural sand & $\begin{array}{c}\text { Inoculated } \\
\text { natural sand }\end{array}$ & Sterilized sand & $\begin{array}{c}\text { Sterilized and } \\
\text { then inoculated } \\
\text { sand }\end{array}$ \\
\hline Hyphae & 5.0 & 18.4 & 0.0 & 5.6 \\
Vesicles & 0.0 & 1.8 & 0.0 & 1.4 \\
Arbuscules & 0.0 & 6.4 & 0.0 & 1.0 \\
Coils & 0.0 & 1.2 & 0.0 & 0.2 \\
\hline Total & 5.0 & 27.8 & 0.0 & 8.2 \\
\hline
\end{tabular}

\section{DISCUSSION}

In experiments on adaptation of sandy everlasting microseedlings to various soil media, the presence of growth-promoting organisms in soil from natural stands was reported ( $\mathrm{S}$ a w i l ska and Jendrzejc z a k, 2009). Subsequent experiments confirmed that natural populations of $H$. arenarium formed permanent functional symbiotic relationships with AM fungi. This was indicated by the presence of typical morphological structures in the plant roots, such as arbuscules, vesicles, coils and hyphae. Arbuscules are intricately branched haustoria located in the cortex cells that are responsible for the nutrient transfer between symbiotic partners, i.e. the AM fungus and the plant. To our knowledge, mycorrhizal status of Helichrysum sp. has been scarcely investigated. Arbuscular mycorrhizal associations were reported in roots of Helichrysum italicum and H. stoechas (L a m o n t, 1984; S te w a r d et al. 1993; M a r e m m a i et al. 2003), whereas in root systems of some Australian Asteraceae, including $H$. apiculatum and $H$. leucopsidum, ectomycorrhizalike structures have been observed ( $\mathrm{W}$ a rcup and Mc Gee, 1983; K o pe and W a r c p , 1986).

Experiments conducted on two natural populations of sandy everlasting reported in this work confirmed that the plant is associated with mycorrhizal fungi. However, no significant relationship between the level of mycorrhizal colonization of plant roots and their generative potential, as well as the potential and actual fertility was found. Our results indicated instead that the ramet mass and the number of generative shoots, inflorescences and flowers per clump depended largely on hydrothermal conditions during the generative development phase. This was especially apparent in 2006 when dry weather did not hinder the development of sandy everlasting but influenced the development of AM fungi. A vigorous development of sandy everlasting in the rainy summer of that year was a result of a low precipitation amount in the two preceding months as well as a strong tolerance of the plant to high temperature. In our studies weather conditions reduced fungi populations that fared better in the years 2005 and 2007.

AM symbiosis is known to alter plant water relations and improve the resistance of plants to drought (A u g é, 2001; 2004). On the other hand, effects of soil drying on the behavior of AM fungal symbionts in roots of variety of plant species have frequently been studied and summarized by A u é (2001). It was found that drought can both increase and decrease levels of root colonization. The results of pot experiments indicated that root colonization is more often increased than decreased. In the field, however, short-term water deficit was observed to decrease AM colonization of plant roots (B olgiano et al. 1983), which is consistent with our results. On the other hand, chronic drought may promote more extensive colonization (B olgi ano et al. 1983; Kuhn et al. 1991). The authors suggested that low soil moisture may cause a decreased availability of phosphorus and an increase of mycorrhizal colonization to provide more phosphorus to the plant. In our study, increased water availability in the seasons 2005 and 2007 resulted in a significantly higher AM colonization of $H$. arenarium. This was consistent with the results of other authors. Alle n et al. (1989) reported that increased soil humidity stimulated growth of roots and development of AM mycelium. J a c o b s o n (1997) suggested that a rapid growth response of mycelium to moisture and production of resilient spores in response to declining moisture may be characteristics allowing AM fungal communities to function under especially arid conditions.

Recently attention has been paid to the effects of AM fungi on the soil itself. As was summarized 
by A u g é (2004), mycorrhizal effects on plant drought resistance and growth under water-stress conditions may be mediated partially by the soil and extramatrical mycelium, regardless whether or not the host plant developed an association with the fungi. The author reported that a mycorrhizal soil had a positive effect on stomatal conductance of non-mycorrhizal plants.

AM extramatrical mycelium is known to influence soil aggregation by production and exudation of glomalin and increase soil water potential in the rhizosphere of AM plants (Bethlenfalvay and Li in d e r m a n, 1992). Extramatrical mycelium may directly contribute to root water uptake $(\mathrm{H}$ ardie, 1985; R u i z-L o zan o et al. 1995) because the hyphae can enter the finest pores in soil and may increase soil-to-root contact in drying soils (e.g. F it t e r , 1985; D a vi e s et al. 1992). Although we did not examine extramatrical mycelium at the study sites, the appearance of high level of AM colonization in 1997 after decreased level in 1996, allow us to conclude that AM fungi were permanently present in the soil and aided the root systems to uptake water from the dried soils.

The succession progress of the phytocoenosis which determines $H$. arenarium interactions of with other plants is also a factor influencing the density, biomass and reproduction of the species. Twenty eight vascular plant species were recorded in sample plots in Fordon (population I), while in Łosiny (population II) only fifteen species were found ( $\mathrm{S}$ a w i l s k a, 2006; 2007; 2008). In both communities sandy everlasting is not the only species that establish mutual symbiotic relationships with AM fungi which may lead to plant species competition for mycorrhizal partner.

Sandy everlasting specimens raised from achenes sown into natural soil medium either augmented with inoculum of Glomus intraradices BEG 87 or sterilized and then inoculated with the fungus were decidedly stronger because of the symbiosis they established with AM fungi (Tabs 5, 6). Positive influence of arbuscular fungi on the root system and shoots of plants raised from seedlings or in vitro plantlets was observed by many authors. Estrada-Luna and D a vi e s (2003) reported an increased concentration of nitrogen, phosphorus, potassium and chlorophyll in plant tissues, photosynthesis stimulation, an increase in leaf area and biomass after soil inoculation with arbuscular fungi during adaptation of Capsicum annuum plantlets. Other studies emphasized an increased survival rate and a faster growth of various plant species with roots colonized by mycorrhizal fungi (D o l c e t Sanjuan et al. 1996; Azcon-Aguilar and B area, 1997; Naqvi and Mukerji, 1998). The transfer of phosphate, nitrogen and a number of trace elements from the AM fungi to the plant is indicated as probably the major effect of the symbiosis, however the influence of AM fungi on host water relations and drought physiology and resistance is also considered as an effect of great importance.

\section{CONCLUSIONS}

1) The conducted studies confirmed that the ability of $H$. arenarium to grow on sandy, acidic soils depends heavily on the presence of arbuscular mycorrhizal fungi and the symbiotic relationship that the plant establish with them. The roots of sandy everlasting from natural stands are permanently colonized by mycorrhizal fungi, but the level of colonization varies and depends on weather conditions.

2) Pluviothermal conditions at the generative phase had a greater influence on $H$. arenarium reproductive processes than the level of AM colonization. The increase in precipitation during the flowering period increased the potential and actual fertility of sandy everlasting and resulted in the highest production of achenes per area unit in the populations studied.

3) Arbuscular fungi promote the growth and development of sandy everlasting at its early development stages. Plants raised from achenes sown into a natural medium (sand) that was either previously inoculated with the fungus Glomus intraradices BEG 87 or first sterilized and then inoculated have a stronger root system and a greater photosynthetic area.

\section{Acknowledgments}

The authors thank Ms. Małgorzata Rumińska, M. Sc. and Mr. Piotr Kornacki, M. Sc., for their excellent help in laboratory experiments.

\section{REFERENCES}

Allen M. E., Riehards J. H., Busso C. A., 1989. Influence of clipping and soil water status on vesicular-arbuscular mycorrhizae of two semi-arid tussock grasses, Biol. Fertil., 8: 285-289.

A u gé R. M., 2001. Water relations, drought and vesicular-arbuscular mycorrhizal symbiosis, Mycorrhiza, 11: 3-42.

Augé R. M., 2004. Arbuscular mycorrhizae and soil-plant water relations, Can. J. Plant Sci., 84: 373-381.

A zcon-Aguilar C., B are a J. M., 1997. Applying mycorrhiza biotechnology to horticulture: Significance and potential, Scientia Horticulturae, 68: 1-24.

B a c S., Koźm ińs k i C., Rojek M., 1998. Agrometeorologia / Agrometeorology, PWN, Warszawa: 169.

Barea J. M., Azcon-Aguilar C., A zcon R., 1991. The role of VA mycorrhizas in improving plant $\mathrm{N}$ acquisition from soil as assessed with ${ }^{15} \mathrm{~N}$, [In:] C. Flitton (ed.), The use of stable isotopes in plant nutrition, Soil Fertility and Environmental Studies, Joint IAEA/FAO Division, Vienna: 209-216. 
Bethlenfalvay G. J., Linderman R. G., 1992. Mycorrhizae and crop productivity, [In:] G. J. Bethlenfalvay and R. G. Linderman (eds), Mycorrhizae in sustainable agriculture, Amer. Soc. Agron. Special Public., Madison, 54: 1-27.

B łaszkowski J., 2004. Przeszłość, teraźniejszość i przyszłość klasyfikacji arbuskularnych grzybów mikoryzowych. / The past, present and future of the arbuscular mycorrhizal fungi classification Kosmos, 53: 17-24.

Bolgiano N. C., Safir G. R., Warnacke D. D., 1983. Mycorrhizal infection and growth of onion in the field in relation to phosphorus and water availability, Journal of the Amer. Soc. Hortic. Sci., 108: 819-825.

B u chw a ld W., 1992. Kocanki piaskowe ginącym gatunkiem. / Sandy Everlasting as a vanishing species, Wiad. Ziel., 34 (5): 5-6.

Davies F. T., Potter J. R., Linderman R. G., 1992. Mycorrhiza and repeated drought exposure affect drought resistance and extraradical hyphae development of pepper plants independent of plant size and nutrient content. J. Plant Physiol., 139: 289-294.

Dolcet-Sanjuan R., Claveria E., Camprubi A., Estaun V., Calvet C., 1996. Micropropagation of walnut trees (Juglans regia L.) and response to arbuscular mycorrhizal inoculation, Agronomie, 16: 639-645.

Estrada-Luna A. A., Davies F. T., 2003. Arbuscular mycorrhizal fungi influence water relations, gas exchange, abscisic acid and growth of micropropagated chile ancho pepper (Capsicum annuum) plantlets during acclimatization and postclimatization, J. Plant Physiol., 160: 1073-1083.

Fa li ńs k a K., 2002. Przewodnik do badań biologii populacji roślin. / A guide to research in plant population biology, Vademecum Geobotanicum, Państwowe Wydawnictwo Naukowe, Warszawa: 587.

Farmakopea Polska 2002 - wydanie VI / Polish Pharmacopoeia - 6th edition: 860-861.

Fijałkowski D., Seroczyńska M., 1974. Kocanki piaskowe [Helichrysum arenarium (L.) Moench] w województwie lubelskim i ich uprawa. / Sandy everlasting [Helichrysum arenarium (L.) Moench] in Lubelskie voivodship and its cultivation, Herba Pol., 20 (4): 363-372.

Fitter A. H., 1985. Functioning of vesicular-arbuscular mycorrhizas under field conditions, New Phytologist, 99: 257-265.

Gawron-Gzella A., Bylka W., Matławska I., 2003. Leki roślinne usprawniające proces trawienia. / Digestion improving herbal drugs, Herba Pol., 49 (3/4): 350-351.

Gemma J. N., Koske R. E., 1997. Arbuscular mycorrhizae in sand dune plants of the north Atlantic Coast of the US: Field and greenhouse inoculation and presence of mycorrhizae in planting stock, J. Environ. Management, 50: 251-264.

Graham J. H., 2001. What do root pathogens see in mycorrhizas?, New Phytologist, 148: 357-359.
Gucwa-Przepióra E., Turnau K., 2001. Arbuscular mycorrhiza and plant succession on zinc smelter spoil heap in Katowice-Wełnowiec, Acta Soc. Bot. Pol., 70: 153-158.

H a r d i e K., 1985. The role of extraradical hyphae in water uptake by vesicular-arbuscular mycorrhizal plants [In:] V. Gianinazi-Pearson and S. Gianinazi (eds) Physiological and genetical aspects of mycorrhizae, Proceedings of the 1st European Symposium on Mycorrhizae, Dijon, 1-5 July: 651-655.

Jakobsen I., R o sendah 1 L., 1990. Carbon flow into soil and external hyphae from roots of mycorrhizal cucumber plants, New Phytologist, 115: 77-83.

Ja c obs on K. M., 1997. Moisture and substrate stability determine VA-mycorrhizal fungal community distribution and structure in an arid grassland, J. Arid Environ., 35: 59-75.

Kope H. H., Warcup J. H., 1986. Synthesized ectomycorrhizal associations of Australian herbs and shrubs, New Phytologist, 104: 591-599.

Kormanik P. P., McGraw A. C., 1982. Quantification of vesicular-arbuscular mycorrhizae in plant roots, [In:] N. C. Schenck (ed.), Methods and pronciples of mycorrhizal research, American Phytopathological Society, Minnesota, St Paul: 37-45.

Koske R. E., Gemma J. N., 1997. Mycorrhizae and succession in planting of beachgrass in sand dunes, Amer. J. Bot., 84: 118-130.

Kuhn D. K., Weber H. C., Dehne H. W., Gworgwor N. A., 1991. Distribution of vesicular-arbuscular mycorrhizal fungi on a fallow agriculture site, I, Dry habitat, Angewandte Botanik, 65: 169-185.

Lam ont B. B., 1984. Specialised modes of nutrition, [In:] J. S. Pate and J. S. Beard (eds), Kwongan, Plant life in the Sandplain, University of Western Australia Press, Nedlands: 226-245.

Maremmani A., Bedini S., Matosevic I., Tomei P. E., Giovannetti M., 2003. Type of mycorrhizal associations in two coastal nature reserves of the Mediterranean basin, Mycorrhiza, 13: 33-40.

Matuszkiewicz W., 2005. Przewodnik do oznaczania zbiorowisk roślinnych Polski. / A guide to Polish plant communities identification, Vademecum Geobotanicum, PWN, Warszawa: 537.

McGonigle T.P., Miller M.H., Evans D. G., Fairchild G. L., Swan J. A., 1990. A new method which gives an objective measure of colonization of roots by vesicular-arbuscular mycorrhizal fungi, New Phytologist, 115: 495-501.

Naqvi N.S., Mukerji K. G., 1998. Mycorrhization of micropropagated Leucaena leucocephata (Lam.) de Wit., Symbiosis, 24: 103-113.

Oża rowski A., 1983. Rośliny lecznicze stosowane w fitoterapii, [W:] A. Ożarowski (ed.) Ziołolecznictwo. Przewodnik dla lekarzy. / Medicinal plants in phytotherapy, [In:] Phytotherapy. A guide for physicians, PZWL, Warszawa: 44-282. 
Pacholak H., Załęcki R., 1979. Sposoby rozmnażania kocanek piaskowych. / Sandy Everlasting propagation methods, Wiad. Ziel., 3: 10-11.

Ruiz-Lozano J. M., Azcon R., Gomez M., 1995. Effects of arbuscular-mycorrhizal Glomus species on drought tolerance: physiological and nutritional plant responses, Appl. Environ. Microbiol., 61: 456-460.

Rut kow sk i L., 2004. Klucz do oznaczania roślin naczyniowych Polski Niżowej. / A key to identification of vascular plants of lowland Poland, Państwowe Wydawnictwo Naukowe, Warszawa: 814.

Sanchez-Diaz M., Hon rubia M., 1994. Water relations and alleviation of drought stress in mycorrhizal plants, [In:] S. Gianinazzi and H. Schüepp (eds), Impact of arbuscular mycorrhizas on sustainable agriculture and natural systems, Birkhäuser Verlag, Basel: 167-178.

S awilsk a A. K., 2006. Wpływ czynników środowiskowych na przebieg kwitnienia Helichrysum arenarium (L.) Moench. / The influence of habitat factors on flowering process of Helichrysum arenarium (L.) Moench, Acta Agrobot., 59 (1): 241-249.

S awilsk a A. K., 2007. The influence of origin of Helichrysum arenarium (L.) Moench individuals on their inflorescence yield and germination ability, Acta Agrobot., 60 (2): 111-116.

S aw ilsk a A. K., 2008. Dynamics of Helichrysum arenarium (L.) Moench populations growing in fallow field on barren soil, Ecological Questions, 9: 93-101.

Sawilska A. K., Jendrzejczak E., 2009. Adaptation of Sandy Everlasting [Helichrysum arenarium (L.) Moench] microseedlings to mineral and organic soils, Polish Botanical Studies, X: (in press).

S mith S. E., Re ad D. J., 1997. Mycorrhizal symbiosis, 2nd Edition, Academic Press, London, Cambridge: 605.

Stewart G. R., Pate J. S., Unkovich M., 1993. Characteristic of inorganic nitrogen assimilation of plants in fire-prone Mediterranean type vegetation, Plant Cell Environ., 16: 351-363.

Thomps on J. P., 1987. Decline of vesicular-arbuscular mycorrhizas in long fallow disorder in field crops and its expression in phosphorus deficiency in sunflower, $\mathrm{Au}-$ stralian J. Agricul. Res., 38: 847-867.

Trzciński W., (ed.) 1989. Systematyka Gleb Polski. / Systematics of Polish Soils, Roczniki Gleboznawcze, 40 (3/4), Państwowe Wydawnictwo Naukowe, Warszawa: 150.

Warcup J. H., McGee P. A., 1983. The mycorrhizal associations of some Australian Asteraceae, New Phytologist, 95: 667-672.

Welc M., Sawilska A. K., Kieliszewska-Rokicka B., Ziółkowska B., Kulczyk M., 2007. Mikoryza arbuskularna kocanek piaskowych Helichrysum arenarium (L.) Moench w warunkach naturalnych i w uprawie szklarniowej, [W:] E. Kępczyńska and J. Kępczyński (eds), Botanika w Polsce - sukcesy, problemy, perspektywy. I Arbuscular mycorrhiza of sandy everlasting Helichrysum arenarium (L.) Moench plants under natural and greenhouse conditions, [In:] Botany in Poland: successes, problems and perspectives, Szczecin, 3-8 September: 148.

\section{Wpływ grzybów mikoryzowych na wzrost i rozwój kocanek piaskowych Helichrysum arenarium (L.) Moench}

\section{Streszczenie}

W dwóch niezależnych eksperymentach poddano ocenie znaczenie kolonizacji korzeni Helichrysum arenarium przez grzyby mikoryzowe, dla wzrostu i rozwoju roślin. W pierwszym doświadczeniu badano powiązanie stopnia kolonizacji korzeni z warunkami pluwiotermicznymi okresu wegetacji i wiekiem naturalnej populacji rośliny. W drugim doświadczeniu, w warunkach kontrolowanych, analizowano wpływ sztucznej inokulacji grzybem arbuskularnym Glomus intraradices na cechy roślin pozyskanych $\mathrm{z}$ siewu niełupek. Wykazano, że warunki termiczno-wodne w okresie kwitnienia kocanek piaskowych mają większy wpływ na procesy reprodukcyjne niż wiek populacji (zaawansowanie sukcesji wtórnej) oraz stopień ich kolonizacji przez grzyby mikoryzowe. Duża ilość opadów w okresie rozwoju generatywnego roślin korzystnie wpływa na płodność potencjalną i rzeczywistą ramet. Obecność w podłożu grzyba arbuskularnego sprzyja wzrostowi i rozwojowi kocanek piaskowych we wczesnych stadiach rozwojowych - mają one lepiej wykształcony system korzeniowy $i$ większą powierzchnię asymilacyjną. 